\title{
Együtt a szakma - Beszámoló a Generációk diskurzusa a regionális tudományról című konferenciáról
}

\section{Bringing the professionals together-Report on the Discourse of Generations conference}

\author{
PÁGER BALÁZS, RÁCZ SZILÁRD
}

A Magyar Regionális Tudományi Társaság X. vándorgyűlését 2012. november 23-án a Generációk diskurzusa a regionális tudományról címü konferencia követte a győri Széchenyi István Egyetemen. A Széchenyi István Egyetem Regionális- és Gazdaságtudományi Doktori Iskolája és az MRTT közös rendezvénye a regionális tudomány eredményeit és új kihívásait tematikus szekciók keretében kívánta áttekinteni. A tanácskozáson a különböző generációk képviselői - a doktoranduszoktól a posztdoktorokon keresztül a professzorokig - egyaránt lehetőséget kaptak a regionális tudomány helyzetének, fejlődésének értékelésére, az aktuális kérdések megvitatására és a jövőbeli feladatok meghatározására. Annak ellenére, hogy tizenegy szekcióban összesen kilencvenhat előadás hangzott el, teljesült a konferencia célja, mert elegendő idő jutott a generációk közötti dialógusra is.

A szekciómunka előtti kerekasztal-beszélgetésen a magyar regionális tudomány meghatározó szereplői vettek részt. A megjelenteket Fekete Dávid, Győr alpolgármestere köszöntötte, aki a regionális tudomány fontosságát hangsúlyozta, amelynek eredményei a gyakorlatban is tetten érhetők a városban és környezetében. A beszélgetés célja alapvetően az volt, hogy a jelenlévők a regionális tudomány lehetséges jövőképeit vázolják fel - Rechnitzer János, az MRTT elnökének felvetése alapján - egy kötetlen és optimista diskurzus keretében. A kerekasztal résztvevői saját nézőpontjukból és filozófiájukból kiindulva igyekeztek választ adni a kérdésekre.

Pálné Kovács Ilona, az MTA KRTK Regionális Kutatások Intézetének (RKI) tudományos tanácsadója szerint a kormányzás és a hatalommegosztás témája eddig viszonylag háttérben volt a tudományon belül, pedig jelentősége még talán nagyobb is a kelet-közép-európai régióban, mint Nyugat-Európában. Nemes Nagy József meglátása szerint napjainkban nincsenek könnyü helyzetben a területi kutatók, de ettől függetlenül mindig is voltak és a jövőben is lesznek olyan területi problémák és kérdések, amelyekre választ kell adni. Az ELTE Regionális

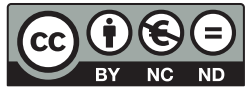


Tudományi Tanszékének vezetője szerint a regionális tudomány jövője szempontjából meghatározó fontosságú, hogy a következő generáció olyan szintű tudást kapjon, amely alkalmas ezen kérdések megválaszolására. Faragó László azzal vitte tovább a gondolatot, hogy a regionális tudományon belül több tudáskészlet is jelen van, és fontos, hogy ezeket ilyen diskurzusokon keresztül harmonizáljuk. A Regionális Kutatások Intézetének igazgatója kiemelte, hogy a regionális kutatók saját „anyatudományaikban” - elsősorban a közgazdaság- és a földrajztudomány területén - is jelentős eredményeket értek el, ezáltal erősödött a területi szemlélet. A térszemlélet széles körü társadalmasítását hangsúlyozta Lengyel Imre is, aki szerint a tértudományokat nemcsak a „saját” (regionális, földrajzi és gazdasági) képzéseken, hanem lehetőség szerint más társadalomtudományi szakok (pl. történelem, szociológia) hallgatóival is meg kellene ismertetni. A Szegedi Tudományegyetem intézetvezető egyetemi tanára kiemelte, hogy fontos az alulról történő integrált szerveződés, a bottom-up szemlélet elsajátítása. A kerekasztal külföldi vendége, Peter Nijkamp három globális megatrendet vázolt fel, amelyekben a regionális tudomány lehetséges jövőjét látja:

- az öregedés, amely komoly hatással lesz a társadalomra (az egészség kérdése) és a gazdaságra (a fogyasztási szokások megváltozása),

- az átrendeződő gazdasági erőviszonyok és pozíciók a világban, amelyben Európának törekednie kell arra, hogy megtartsa eddigi helyzetét, valamint

- az urbanizáció és az agglomerációk kérdése, mivel a városok népessége folyamatosan nő, a Föld népességének már több mint fele városokban él - ez az arány Európában még magasabb -, így releváns a kihívás, hogy a városok helyét és lehetőségeit kutassuk a válságot követő gazdasági környezetben.

Az amszterdami Free University professzorának jövőképére többen reflektáltak. Lengyel Imre meglátása szerint a magyar regionális tudomány számára Magyarország területi folyamatainak megértése az egyik legfontosabb kérdés. Horváth Gyula ehhez kapcsolódóan úgy látta, hogy az említett megatrendek apróbb elemeinek ismereteire - például hogy ezek milyen hatással lesznek hazánkra - van szükség. Az MTA Regionális Tudományi Bizottsága elnökének jövőképe szerint a területiség továbbra is fontos elem marad, de az európai uniós strukturális támogatások vizsgálata helyett inkább azt kellene kutatni, hogyan tud az ország meghatározó szereplővé válni az Európai Unió közös piacán. Sajnos hiányoznak azok a kompetenciák, amelyek ezt a folyamatot segíthetnék. Rechnitzer János kifejtette, hogy a rendszerváltás egy elhúzódott, bizonyos részeiben még mindig feltáratlan, évtizedes átalakulási folyamat volt; lényeges kérdés a kifutásait mérni és felderíteni, ehhez többek között intézményekre és diskurzusokra van szükség. Pálné Kovács Ilona Peter Nijkamp véleményére reagálva jelezte, hogy nyugat-európai szemmel fontos folyamatok másképp müködnek itt, a periferikus területeken, és - mivel eltérőek a hangsúlyok és mások a kérdések - nem biztos, hogy mindenben a nyugati trendeket kell követnie a térségnek. Varga Attila a regionális tudományon belül két, egy- 
mással szemben álló elképzelést vázolt: a térsemleges (space-neutral) nézet az agglomerációk, innovációs központok, azaz a magrégió fejlesztését támogatja; a téralapú felfogás pedig a kiegyenlítettebb fejlődésre épül és figyelembe veszi a kis- és középvárosok fejlesztési sajátosságait és lehetőségeit. A helyi fejlesztések megvalósításához komplex elgondolásokra van szükség, ennek megvalósítása mind a fejlesztéspolitikában, mind a gazdaságmodellezésben komoly energiákat igényel - zárta hozzászólását a pécsi Regionális Politika és Gazdaságtan Doktori Iskola vezetője. Faragó László szerint a korábbi duális szemléletet félretéve az új fejlesztéspolitikai megközelítésben a centrumokat együtt kell kezelni a perifériával, a falut a várossal. Továbbá a jelenlegi egyetlen európai magrégió helyett miért ne lehetne Közép-Európa egy olyan centrumtérség, amely az európai uniós szinten decentralizált fejlesztéspolitika célpontjává válhatna?

A hallgatóság számos hozzászólás, vélemény és kérdés megfogalmazásával kapcsolódott be a beszélgetésbe. Szlávik János a dunántúli és észak-magyarországi térségek, városok közötti fejlettségi különbségek növekedésének problémáját említette. Barta Györgyi egy optimista-pesszimista ellentmondást vélt felfedezni: ha Magyarországra fókuszáló kutatási témákról beszélünk, akkor jellemzően borúlátóbb a hangulat, az optimista nézőponthoz ki kell tekinteni az európai uniós folyamatokra és lehetőségekre. Vincze Mária úgy látta, hogy a tudomány szempontjából nincs ok a pesszimizmusra, derűsen kell látni a helyzetet, kutatni mindig - még vészterhes időszakokban is - lehetett, legfeljebb a keretfeltételek változtak. Katonáné Kovács Judit Pálné Kovács Ilona gondolatait megerősítve amellett foglalt állást, hogy a helyi gazdaságfejlesztés és a részvételen alapuló kormányzás központi kérdés lesz a jövőben. Peter Nijkamp az elhangzottakra reflektálva kiemelte, hogy nagyon sok kérdés azzal kezdődik: Mi a jövője...? Feltételezése szerint a jövőt előre jelezni nagyon nehéz a mai korban, mert már nem az ókori világot éljük, amikor a hadvezérek - „egyetlen jövőkutatóként" - a támadás megkezdése előtt a delphoi jósnőt kérdezték meg a lehetséges háború kimeneteléről. A holland professzor az ókori hasonlatnál maradva utalt az információcsere folyamatának fontosságára, amely akkor pl. a harcoló rabszolgák között történt meg a sporteseményeken. Ma még nagyobb jelentősége van az összegyűjtött tudásnak, a tudományosságnak. Nem az a fontos, hogy optimistán vagy pesszimistán látjuk-e a jövőt, hanem a tudásra (a tudományra) való fókuszálás a lényeges. Nemes Nagy József arra hívta fel a figyelmet, hogy nem szabad engedni a magyar regionális tudomány elért színvonalából. Nem feltétlenül jó, ha Magyarország társadalmi-gazdasági folyamatai a nemzetközi kutatások újra divatos kérdéseivé válnak, mert legutóbb a rendszerváltáskor volt kurrens ezt a térséget vizsgálni. Rechnitzer János azzal zárta a kerekasztal-beszélgetést, hogy reméli, a jövőben gyakrabban kerül sor hasonló diskurzusra a regionális tudomány jövőjéről.

A konferencia szekcióprogrammal folytatódott. Az első szekció átfogóan próbálta megragadni a térelmélet és a területfejlesztés kapcsolatát. A vitaindítót Faragó László (RKI, Pécs) tartotta a tértudomány(ok) kihívásairól. Hangsúlyozta a 
regionális problémák társadalmi oldalról történő vizsgálatát, felhívta a figyelmet a különböző, de mégis szinergiában együttműködni képes tudásközösségek kialakításának fontosságára. Véleménye szerint a térbeli szerkezetek, rendszerek egységes tértudományban értelmezhetők, ennek révén lehet erősíteni a közös gondolkodást a többi társadalom- és műszaki tudománnyal. Bernek Ágnes (ZSKF Geopolitikai Kutatóközpont) a térelméletet globális felfogásban vizsgálta, igen pesszimista európai jövőképet vázolt fel Nyugat és Kelet új értelmezése a 21. században címmel. Az új évszázadban szerinte geopolitikai gondolkodás és problémalátás nélkül nem lehet nagytérségi tervezést és fejlesztéseket megvalósítani, mivel a világ új hatalmi és gazdasági pólusai gyorsan és határozottan reagálnak az érdekeik ellen ható bármilyen térségi szerveződésre. Szilvássy István (Magyar Település- és Területfejlesztők Szövetsége) a kiemelt térségek problémájáról értekezett. A hallgatóság egybehangzó vélekedése szerint mindig is voltak térségi kiemelések, amelyek háttérbe szorították a kevésbé fejletteket. Czirfusz Márton (RKI, Budapest) a gazdaságról való tudás térbeliségét a magyar gazdaságfejlesztés térszemléletének kritikájával illusztrálta. Friss szemléletű előadásában a foáramú közgazdaság-tudomány és a regionális tudomány kapcsolatát elemezte, kitért a gazdaságföldrajzot érintő kihívásokra, aláhúzta a kritikai gazdaságföldrajz szükségességét. Lux Gábor (RKI, Pécs) a globális kihívásokat (versenyképesség, gazdasági válság hatásai) és az azokra adott válaszokat, alkalmazkodási lehetőségeket vette számba a közép-európai és a magyar nagyvárosi agglomerációk szemszögéből. Horváth Sarolta Noémi (SZTE GTK) a városrégiók lehatárolásának módszertanát és versenyképességük mérésének lehetőségeit elemezte. Koltai Zoltán (PTE FEEK) a Pécs2010 program változó megítélését és hatásait ismertette. Az előadók sorát Páger Balázs (PTE KTK) zárta, aki a tudásintenzív iparágak lehetőségeiről értekezett a visegrádi országokban. A heterogén témákat az elmélet és gyakorlat viszonyrendszere füzte egybe.

Kelet-Közép-Európa területi folyamatainak megvitatására külön szekció szerveződött. Három előadás a nagytérségi átalakulást elemezte. Tóth Tamás (SZE RGDI) a kelet-közép-európai országok makrogazdasági versenyképességét a jármüipar telepítése szempontjából mutatta be. Az országok versenyképességi indikátoraira épülő modellben a beáramlott müködőtőke-állománnyal, illetve -volumennel kereste az összefüggést. Egri Zoltán (SZIE Tessedik Campus) a közép- és kelet-európai EU-tagországok térformáló tényezőit vizsgálta többváltozós adatelemzéssel. A modell térképi ábrázolása alátámasztotta azon vélekedéseket, hogy a területi különbségek jelentős növekedése mellett az unión belül egy második, északkeleti gazdasági magterület azonosítható. Adatok hiányában a Nyugat-Balkán országai nem szerepelhettek az elemzésben. A „fehér folt” problémáját Rácz Szilárd (RKI, Pécs) igyekezett oldani A Balkán településhálózatának ciklikus fejlődése címü előadásával. A térszerkezet és a városhálózat alakulását befolyásoló térségi sajátosságok közül szerinte a politikai instabilitás, a határok és súlypontok állandó változása a legerőteljesebb, a struktúraváltozás (államosodás) több országban napjainkban is tart. Bajor Tibor (ÁVF) Kárpátalja közlekedésének történeti 
fejlődését és lehetséges szerepét vázolta az eurázsiai tranzitforgalomban. Az előadó részletesen kitért a kelet-közép-európai térség logisztikai dilemmáira és az új selyemút vonalvezetéséért vívott küzdelmekre. A makroregionális áttekintések után szó esett a magyarországi lakásépítések földrajzáról is. Buskó Tibor (NKE KTK) a kormányzati törekvések és intézkedéscsomagok hatásait vette számba, a lakáspolitika területi következményeit is értékelve.

A harmadik szekció a regionális tudomány módszertani kérdéseivel, a területiség modellezésének többféle aspektusával foglalkozott. Nagyné Molnár Melinda (SZIE GTK) a falukutatás vizsgálati technikáit és eredményeit konkrét példákon mutatta be. A hallgatóság kérdéseket fogalmazott meg arról, hogyan fogadják a települések a kutatókat, mennyire nyitottak a falukutatásra. Az elöadó válaszából megtudhattuk, hogy a terepmunka előkészítéseként a településvezetők és helyi egyesületek támogatását igyekeznek elérni. Szalkai Gábor (ELTE Regionális Tudományi Tanszék) a járások kialakításának módszertani lehetőségeit elemezte. Bemutatta a járásközpontok kiválasztásának és vonzáskörzeteik lehatárolásának lehetséges megoldásait. A Bibó-féle alapelvekre épülő optimális lehetőségeket azonban a kormányzat nem vette figyelembe a járásrendszer kialakításakor. Farkas Máté Bence (ELTE RTT) a komplex fejlettségi mutatók használatának lehetőségeiről tartott előadást. A komplex mutatók mellett és ellen is sok érv felhozható, használatukról nem várható közmegegyezés. A hivatalos statisztikusok többsége ellenzi alkalmazásukat, de a bonyolult, nehezen számszerüsíthető jelenségek (pl. boldogság, jólét) egyetlen indexbe való tömörítése továbbra is ellenállhatatlan kísértést jelent. Az összefüggés-vizsgálatok hálózaton belüli alkalmazásának lehetőségeire Vida Zsófia (ELTE RTT) érdekes kutatást hozott példaként, amelyben egy kórus tagjai közti barátságokat modellezte. Erről a kapcsolati hálózatról az mondható el, hogy a barátságot a földrajzi paraméterek nem magyarázzák. Poreisz Veronika (SZE RGDI) a gravitációs modellt mutatta be és gyakorlati példákat hozott kiskereskedelmi alkalmazásának lehetőségeiről. A modellel várostérségeket lehet lehatárolni, a nemzetközi kereskedelmet vagy akár a településen belüli mozgásokat modellezni. Süle Edit (SZE KGYK) az idő- és térhasználat mérési lehetőségeit ismertette. Az időföldrajz azt vizsgálja, hogy mindennapi mozgásaink milyen korlátok mellett és milyen áldozatok árán valósíthatók meg.

A Kohézió és regionális politika című szekció vitaindító előadásában Lunk Tamás (Vital Pro Kft.) a térbeliség és fejlődés aspektusából, a kohéziós politika új irányából adódó lehetőségeket és feladatokat mutatta be. Olyan fő kérdésekre kereste a válaszokat, mint: Kikényszeríti-e az Európai Unió a térbeliség hangsúlyos szerepeltetését? Ha igen, akkor milyen mértékben és minőségben? Mennyire vagyunk felkészülve erre? A témához illeszkedve Illés Dóra (PTE Regionális Politika és Gazdaságtan Doktori Iskola) Magyarország szempontjából pontról pontra ismertette az Európa 2020 stratégiát, a kohéziós politika 2014-2020-as programját és ezek viszonyrendszerét. Az általános kérdéseket követően három határmentiségre fókuszáló előadó következett. Soós Edit (SZTE ÁJK) az európai 
területi együttműködési célkitűzés perspektíváit vázolta fel, különös tekintettel a harmadik országok részvételére. Gyulai Tamás (Euro-Tech Hungary Kft.) A határon átnyúló innovációs stratégiák lehetőségei a klaszterekre építő gazdaságfejlesztésben című előadásában a Temesvár-Szeged-Újvidék-háromszögre fókuszált. Ricz András (Regionális Tudományi Társaság, Szabadka) mindezt a Vajdaság szempontjából értékelte, az EU határon átnyúló programjainak gazdasági hatásait taglalva.

A legtöbb előadót az agrár- és vidékpolitikával foglalkozó szekció vonzotta. Vincze Mária (Babeș-Bolyai Tudományegyetem) bevezető előadásában a vidékfejlesztés dilemmáit európai és romániai perspektívából vizsgálta. A vidéki térségek sajátos jellemzőkkel, problémákkal rendelkeznek, ez teszi szükségessé az önálló vidékfejlesztési politikát. A fejlesztéspolitika azonban normatív értékeket is megfogalmaz: Biztosan a fejlett ipari országok értékrendjét kell követnünk? Van-e közgazdasági megalapozottsága a vidékfejlesztési politikának? Ismerjük az önálló helyi kezdeményezéseket? Valóban ezeket karolja fel a vidékpolitika? Milyen a vidéki társadalom, amelyet „fejleszteni” szeretnénk? A számos kérdésre a szekció résztvevői az előadóval együtt keresték a válaszokat. Katonáné Kovács Judit (DE AGTC) fejlesztéspolitikára fókuszáló előadása javaslatot tett az erőforrások és a szabályozó eszközök összehangolására a 2014-2020 közötti időszakban. Kovács Teréz (PTE BTK) a nagyvárosi közösségi kertek sajátosságait berlini, budapesti és pécsi példákon keresztül ismertette. A többi elöadás a vidéki gazdasághoz kapcsolódott. G. Fekete Éva (ME GTK) a regionális gazdasági együttműködések sajátos formáival, a helyitermék-klaszterekkel foglalkozott. Koós Bálint (RKI, Budapest) kollégáival a hazai mezőgazdasági foglalkoztatás főbb trendjeit mutatta be. Az agrárfoglalkoztatottak meghatározó jellemzői: alulképzettség, alulfizetettség, férfidominancia és elöregedő korszerkezet. Máté Péter (MVH) dél-alföldi tapasztalatokra támaszkodva a vállalkozások és a helyi akciócsoportok oldaláról közelítette a vidékfejlesztési gyakorlatot. Csata Andrea (Sapientia Erdélyi Magyar Tudományegyetem) a fejlesztéspolitika gazdaságszerkezeti hatásait erdélyi példákon ismertette, majd vázolta az állami szerepvállalással kiküszöbölhető szerkezeti hiányosságok fejlesztési prioritásait. Kis Krisztián (SZTE MK) a vidékgazdaság fogalmát és típusait ismertette. A vidékgazdaságok teljesítményét alapvetően meghatározza, hogy a helyi közösségek milyen válaszokat akarnak és tudnak adni az őket érő kihívásokra, így a helyi kultúra a vidékgazdaságok jellemzőinek legfőbb meghatározója. Murányi Péter (SZE RGDI) a kultúra és a vidék kapcsolatát elemezte a fejlődőképesség, fejleszthetőség szempontjából.

A környezetkutatás és a regionális tudomány abból a szempontból különbözik a többi tudományágtól, hogy mindkettő olyan összetett folyamatokat vizsgál, amelyek csak számos szakterület (különböző társadalom-, természet- és műszaki tudományok) együttes tudáskészletével magyarázhatók. A hatodik szekció a környezeti és a területi kérdések kapcsolódási pontjait kereste. A kis létszámnak köszönhetően több idő jutott az előadásokkal kapcsolatos kérdések, véle- 
mények megfogalmazására, a dialógus jó hangulatban és eredményesen folyt. Három előadás nagytérségi folyamatokkal foglalkozott. Szép Tekla (ME GTK) az energia gazdasági szerepét értékelte Kelet-Közép-Európában a rendszerváltozást követő időszakban. Varjú Viktor (RKI, Pécs) a visegrádi országok és Románia környezeti politikáját vizsgálta, célja a környezettudatosság összehasonlító értékelése volt. A stratégiai környezeti vizsgálat és a környezeti hatásvizsgálat területi tervezésben betöltött szerepéről vita alakult ki. A hallgatóság szerint a környezetvédelemnek a területi tervezés szerves részét kell képeznie, nem utólag kellene „integrálni” azt. Nagy Imre (Újvidéki Egyetem) a Nyugat-Balkán környezeti problémáit taglalta, különös tekintettel a határon átnyúló terhelésekre. Mezei Cecília (RKI, Pécs) a hazai önkormányzatok energetikai fejlesztéseiről szólt. A jelenlévők azt a konzekvenciát vonták le, hogy Magyarországon a településeknek nincs klímastratégiája, a területi tervezésben csak kismértékben jelenik meg a környezetvédelem és a környezettudatos gondolkodás. Suvák Andrea (RKI, Pécs) a települések környezetvédelmi törekvéseiben megjelenő etikai vonatkozásokat vizsgálta. Danka Sándor (PTE KTK) Biogázüzemek a valóságban - a kaposszekcsői biogázüzem címmel egy gazdaságilag fenntarthatatlan fejlesztést mutatott be. Pinke Zsolt (SZIE Környezettudományi Doktori Iskola) egy tervet ismertetett a Rákos-patak tájrevitalizációjára. A hallgatóság tetszését fejezte ki az egészségügyi hatásokat is számszerü adatokkal vizsgáló ötlettel (kerékpárút a Városligettől Gödöllőre) kapcsolatban.

A Duna és területi fejlődés szekció résztvevői kurrens témát jártak körül. Az Európai Unió Duna régió stratégiájának megvalósíthatósága, az azt övező ellentmondások és a stratégia által kínált fejlesztési lehetőségek több nézőpontból is megvilágíthatók. Hardi Tamás (RKI, Győr) A Duna-térség térfejlődése és a meg nem valósult fejlesztések címü indító előadása megalapozta a későbbi vitákat. Arra mutatott rá, hogy a Duna medencéjében rejlő jelentős gazdasági-kulturális fejlődési potenciál kiteljesedését földrajzi, geopolitikai, civilizációs eltérések és birodalmi ellenérdekeltségek akadályozták meg. Napjainkban ezeknek azért van jelentősége, mert a fejlesztési stratégiák nem minden esetben veszik figyelembe a társadalmi mélyrétegekben meghúzódó tényezőket, így jövőbeni eredményességük is megkérdőjeleződhet. Fekete Dávid (Győr megyei jogú város) előadása a Duna-stratégiában kitüzött célok és a hozzájuk rendelt pénzügyi eszközök közötti egyensúlytalanságra mutatott rá, amelyet az EU következő programozási időszakában a még kevesebb támogatás súlyosbít. Mindez hiteltelenné teheti az érdekeltek szemében a programot. Bencze Edit (Kodolányi János Főiskola) a nem európai uniós tagállamok oldaláról vizsgálta a kérdést. A tanácskozás második felében a Duna-térséget jellemző társadalmi tényezők sokszínűségéről folyt a diskurzus. Bokor Béla (Határokon Túli Magyarságért Alapítvány) a közösségek, a kultúra és az identitás oldaláról tekintette át a Duna-tájat. Minorics Tünde (PTE FEEK) a Duna-Dráva-térség kulturális értékmentési tevékenységeit mutatta be. Kovács Péter (PTE Földtudományi Doktori Iskola) a folyó mint innovációs tengely értelmezésére tett kísérletet. A Duna nyugat-kelet irányú közvetítő szerepe 
minden esetben megjelenik, a vizsgált kulturális innovációk többségében azonban csak a Közép-Duna-medencére terjednek ki. Pintér Tibor (SZE RGDI) a térségi intézményi fejlettséget és annak változásait elemezte. A viták tanúsága szerint értéket jelent a makrorégió heterogenitása, melyből fejlődési impulzusok születhetnek. Az identitás változásai, az innovációs folyamatok terjedésének iránya és civilizációs határvonalaknál jellemző blokkolódása, a fenntarthatósági probléma erőteljesebbé válása együttesen vezet ahhoz, hogy a fejlesztéseket tervezőknek komplexen kell értelmezniük a térszerkezet kedvező irányba való befolyásolását. Ehhez a tudományos eredmények és kapacitások rendelkezésre állnak.

A legtöbb érdeklődőt a helyi és regionális gazdaságfejlesztés témájú szekció vonzotta. A városok fejlettségét többen is vizsgálták. Barsi Boglárka (RKI, Győr) a Smart cities-kutatás eredményeit mutatta be. A felmérésből kiderült, hogy a hazai városok az „okos” várossá válás több feltételének megfelelnek, ugyanakkor a nemzetközi élvonaltól még jelentős a lemaradásuk. A cél nem a vizsgált városok rangsorba állítása volt, hanem egy módszertan kidolgozása és nemzetközi benchmarkok alkalmazásával annak feltérképezése, hogy az egyes városoknak milyen irányokba szükséges elmozdulniuk egy élhetőbb település kialakításához. Enyedi-Tiner Klára (SZIE Regionális Tudományok Doktori Iskola) a Balaton-parti fesztiválokat és azok hatásait tekintette át. A hallgatóság szerint a kutatást a kisvárosok kulturális gazdaságának számszerü vizsgálatával célszerü folytatni. Egyed Ildikó (RKI, Pécs) a fenntartható városfejlesztés - a posztkarbon kompakt város felé vezető út - mintapéldáját, Grenoble helyi politikai célkitüzéseit és eredményeit mutatta be. A tanácskozás másik sarokpontja a regionális gazdaságfejlesztés volt. Kovács Áron (PTE KTK) a Pécs-Pogányi repülőtér regionális szerepét a gazdaságra gyakorolt hatás elemzésével mutatta be. A hozzászólók szerint át kellene gondolni, hogy szükséges-e ez a szolgáltatás, miért érdemes működtetni, ha évek óta adósságot termel. A fejlesztés költségeit és a repülőtérhasználat indikátorait célszerü lenne bevonni a vizsgálatba. Dorogi Zoltán (Észak-Alföldi Regionális Fejlesztési Ügynökség) a klaszterizációt mint a helyi gazdaságfejlesztés egyik lehetséges eszközét az Észak-alföldi régió példáin ismertette. Ez a fajta fejlesztéspolitika csak ott lehet sikeres, ahol a szükséges kritikus tömeg rendelkezésre áll és önfenntartó, nemzetközileg versenyképes klasztert eredményez. Bálint István (Vajdaság) tanulmánya a regionális fejlődés vajdasági problémáiról szólt. A tartomány alkotmányos helyzetének rendezése (pl. az önálló költségvetés tényleges „visszautalása”) nélkül nem sok remény van egy új növekedési pályára. Ezzel kapcsolatban felmerül az az általános dilemma, hogy a gazdasági bajok okozzák-e a politikai zavarokat, vagy éppen fordítva. Mezei Katalin (NYME MÉK) az (agrár)egyetemek harmadik funkciójáról - a vállalkozói tevékenységről - és ezek helyi gazdaságfejlesztésben betöltött szerepéről tartotta előadását. Nemzetközi összevetésben a hazai egyetemek elsősorban a finanszírozás szempontjából (államilag támogatott magas hallgatószám) különböznek. A téma aktualitása kapcsán felmerült, hogy kivonulhat-e az állam a felsőoktatásból. Az egyetemek az önfenntartás miatt egyre inkább rá vannak 
kényszerítve a pályázati és vállalkozási tevékenységre. Három előadó a társadalmi szempontokat helyezte témája középpontjába. Málovics György (SZTE GTK) egy szegedi esettanulmány tanulságait levonva a részvételi akciókutatás szerepét vizsgálta a helyi szintű társadalmi kirekesztés elleni küzdelemben. Oláh Izabella (SZIE RTDI) a közösségfejlesztés alapelveit ismertette. A társadalmi igazságosság, egyenlőség, részvétel, tanulás, együttműködés, élhetőség értékeinek gyakorlati átültetésével beszélhetünk ténylegesen közösségfejlesztésről. Szilágyi Dániel (ELTE TTK) a hazai egészségi állapot területi különbségeit a válságokra fókuszálva elemezte.

A Piaci szereplók és hálózatok a térgazdaságban címü szekcióban igen sokszínü, több társadalomtudományt is érintő előadásokat hallgathattak meg a résztvevők. Sikos T. Tamás (SZIE GTK) a budapesti agglomeráció kereskedelmi és bevásárlóközpontjainak gazdasági válság hatására bekövetkező hanyatlását mutatta be. Koós Bálint (RKI, Budapest) a hazai atipikus foglalkoztatási formák terjedéséről, Lukács Amarilla (NYME KTK) a magyarországi klaszterek fenntarthatóságának vizsgálatáról szólt. Ezt egy makropénzügyekkel foglalkozó blokk követte. Zsibók Zsuzsanna (RKI, Pécs) hazánk területi inflációs adatait kiszámolva kimutatta, hogy a megyék között létezik inflációs különbség. A hozzászólások főleg a kamatlábak számítási módjához kapcsolódtak. Forman Balázs (BCE GTK) a felelőtlen spanyolországi befektetések alapján azt elemezte, hogy miként járultak hozzá a közös európai források a jelenlegi válsághoz. A vita a külföldi befektetőktől való függés mértékéről zajlott. A szekció következő előadásai a pénzintézetekkel foglalkoztak. Gál Zoltán (RKI, Pécs) a magyarországi takarékszövetkezetek helyi beágyazottságáról beszélt. A jelenlévők a kistelepüléseken tapasztalható monopolhelyzetre, valamint a falusi lakosság betétgyűijtési és hitelezési szokásaira kérdeztek rá. Kovács Sándor Zsolt (RKI, Pécs) a green banking gondolatát és a hazai bankok társadalmi felelősségvállalását mutatta be. A reflexiók az iszlám világban terjedő moral banking koncepciójára hívták fel a figyelmet. A következő előadásokban az innovációé volt a föszerep. Garaj Erika (Edutus Főiskola) az innovációs együttműködések határ menti lehetőségeiről, Csizmadia Zoltán (SZE Szociális Munka Tanszék) a hazai kkv-szektor kapcsolathálózati struktúráiról, Grünhut Zoltán (RKI, Pécs) az izraeli K+F-ráfordításokról és azok gazdasági hatásairól referált.

A regionális innováció rendszereivel külön szekció foglalkozott. Elekes Zoltán (SZTE GTK) a komplex rendszerek jellemzőinek témakörét járta körül, arra kereste a választ, hogy milyen szakpolitikai következményei vannak a regionális innovációs rendszerek komplex rendszerként történő értelmezésének. Bajmócy Zoltán (SZTE GTK) előadásában azt mutatta be, hogy miként adhatók meg az innovációpolitika körvonalai, amennyiben azt a növekedésorientált keret helyett a képességszemléletre építjük. Savanya Péter (SZTE GTK) a társadalmi tőke - mint az innováció és regionális fejlődés mozgatórugója - fogalomrendszerét ismertette. A living lab-formáció elméleti hátteréről Füzi Anita (SZE RGDI) számolt be. Az innovációs modellek eltérő megközelítéseit sorra véve kitért arra, hogy a 
vállalkozások számára egy ilyen együttműködés milyen előnyökkel járhat. Lengyel Balázs (IBS, Budapest) az online közösségi hálózatokban rejlő lehetőségeket mutatta be, mely új eszközként jelenhet meg az innováció terjedésének és rendszereinek feltérképezésében. Előadása során rámutatott a közösségi hálózatok adatelemzési nehézségeire. A kelet-közép-európai autóipari tudástranszferek földrajzi dimenzióit Smahó Melinda (SZE KGYK) tárta a hallgatóság elé. A vizsgált országokban egyértelműen elindult a jármüipar funkcionális megújításának folyamata, bár a periferikus helyzetből való kitörés még nem valósult meg teljes mértékben. Sebestyén Tamás (PTE KTK) Régióközi tudáshálózatok minőségének hatása a kutatási teljesítményre című előadásában taglalta a hálózatminőség-index elemeit és alkalmazhatóságát. Gajzágó Éva (SZE RGDI) egy empirikus kutatás eredményeit mutatta be arról, hogy milyen szerepet töltenek be a közvetítő szervezetek a regionális innovációs rendszerben. A jelenlévők véleménye szerint bár a fejlett országok példáját követtük az innovációs rendszer kialakításánál, hazánkban érdemes lenne a közeljövőben a helyi sajátosságokra, lehetőségekre építkezni. Két előadó a dél-magyarországi regionális innovációs teljesítménnyel foglalkozott. Kocsis Tamás (DDRIÜ) a Dél-Dunántúl K+F+I-helyzetképét és kitörési pontjait vázolta gyakorlati példákkal. Vas Zsófia (SZTE GTK) a tudásintenzív iparágak innovációs tevékenységét meghatározó tényezők vizsgálatára fókuszált a Dél-alföldi régióban. A szekciómunkát követően alakuló ülést tartott az MTA Regionális Tudományi Bizottság Regionális Innovációs Albizottsága.

A tizenegyedik szekció témája a területi kormányzás volt. Kaiser Tamás (Pannon Egyetem, Veszprém) a folyamatosan változó governance-koncepciókról beszélt. A hallgatóság egyetértett abban, hogy a fogalom inflálódásának valószínűségét növeli, ha az aktuális kutatások arra irányulnak, hogy az adott témának megfelelő tartalommal töltsék meg a kormányzás definícióját. Nagyházi György (NFM Fejlesztési Koordinációs Főosztály) az új területfejlesztési rendszer hátterét világította meg tulajdonjogi, szervezési és finanszírozási kérdések irányából. A prezentációt követő diskurzus a megyék és a járások anyagi szuverenitásának biztosítékairól folyt. Zongor Gábor (Települési Önkormányzatok Országos Szövetsége) kiemelte, hogy a járások kialakításakor elsődleges szempont a korrupció kiküszöbölése és az önkormányzatok önállóságának megtartása. Ennek megvalósításáról nem volt közmegegyezés, de a jelenlévők egyetértettek a jegyzői felelősség és szerepkör fontosságában. Zsom Brigitta (ELTE RTT) az elektronikus közigazgatást a többszintű elemzés módszerével vizsgálta. Reisinger Adrienn (SZE KGYK) ismertette az aktív demokrácia fogalmát és működésének gátjait. A hozzászólások a kiemelkedően eredményes önkormányzatok, polgármesterek által generált helyi „párbeszédeket” elemezték. Agg Zoltán (Pannon Egyetem, Veszprém) a választási rendszer és a területfejlesztési intézményrendszer változásainak összefüggéseiről értekezett, különböző régióbeosztásokat mutatott be. A hallgatóság részéről pró és kontra érvek hangzottak el a Balaton, a NUTS2 szintű és az önszerveződő régiókkal kapcsolatban. A város és vonzáskörzete közigazgatási szempontból fragmentált, a sokszorosan szabdalt és konf- 
liktusokkal terhelt tér egysége együttmüködés segítségével hozható létre. Somlyódyné Pfeil Edit (SZE KGYK) a magyar nagyvárosi agglomerációk - Győr, Pécs és Miskolc - intézményesítésének problematikáját tárgyalta több nézőpontból. Kérdések a fejlesztési célokról (közlekedés, munkahelyteremtés, gazdaságfejlesztés) érkeztek. A szekcióban aktuális témákat vitattak meg, ennek köszönhetően minden előadásról folyt rövidebb-hosszabb dialógus.

A konferencia jó hangulatú és több szempontból is eredményes volt. Sikerült elérni, inspirálni a különböző generációkat, a tanácskozásokon számottevő igény és lehetőség mutatkozott a szakmai vitákra. Szembetűnően nagy volt az érdeklődés, közel száz előadó vett részt az eseményen (az előadások elérhetők a társaság honlapján: http://www.mrtt.hu). A tucatnyi gyakorlati szakember jelenléte jelezte, hogy a térbeliség nem csak a kutatók számára fontos. A szekciók szerteágazó tematikája átfogóan szemléltette a regionális tudomány sokszínűségét, komplexitását. A visszajelzések alapján jó volt találkozni és diskurzust folytatni a regionális tudományról. Új generációk jönnek, ez természetes és szükségszerü. A lényeg nagyon egyszerü: ösztönözni, segíteni kell a követőket és megbecsülni az előttünk haladókat. A recept ennyi és nem több. Éljen a regionális tudomány! 